\title{
A Child Language Development
}

Kyoko Saito

\section{[1. Introduction: ]}

The purpose of this project was to observe how a child developed her first and second languages and how her family and her social environment influenced her language development.

[2. Informant:]

The informant, Yoko, was born on July 7th 1993 in Sapporo. Her mother, Elizabeth, is American and graduated from Yale University with a Ph.D in biochemistry. Before Elizabeth came to Japan, she worked for a laboratory as a biochemist. Soon after she got married to a Japanese man, she came to Japan. She then worked for the YMCA in Sapporo as an English teacher teaching English conversation to kindergarten pupils. Yoko's father graduated from one of the Japanese national universities with a Ph.D in biochemistry. He taught biochemistry at one of the universities in Sapporo. Yoko has a five-year-old brother, Satoshi. He went to a kindergarten. Before he entered kindergarten, Satoshi did not have any opportunity to interact with other children of the same or similar age.

He communicated with his parents only in English, with the staff at the YMCA using both English and Japanese, and with his father's students using English and Japanese. He never used childish Japanese. It is better to say that he did not acquire children's language because he did not interact with children who were Japanese or native English speakers. He acquired and learned Japanese with his father's university students and mono-lingual Japanese TV programs. When I, Kyoko, communicated with Satoshi in Japanese, I felt as if I were speaking to a small adult.

Yoko's mother asked me to use only English when I communicated with Yoko. It was because she was afraid that Yoko would be confused if people spoke both languages to her. Elizabeth's social environment was limited. Until her son entered kindergarten, she communicated only with her husband, her husband's students, and YMCA's staff. After Satoshi entered elementary school, she communicated with Satoshi's friends and their mothers in Japanese. Elizabeth often read Japanese fairy tales to Yoko in Japanese. When Yoko picked up a book or books, she always picked up Japanese books.

\section{[3. Explanation of perception, production, and four language approaches:]}

The syntactic approach was advocated by Chomsky. "Chomsky proposes as a theoretical construct a language acquisition device (LAD), which accepts as input the primary linguistic data and has as output a grammar of the language from which the data have been drawn." (Elliot, page 7,8) Also "Chomsky believes in a strong innate 
component to language acquisition." (Elliot, page 28)

The behaviorist approach was advocated by Skinner and his associates. They focused on the imitation and reinforcement hypothesis of language development.

The cognitive approach was advocated by Piaget, Vygotsky, and Bruner. Piaget proposed that language development is closely related to cognitive development. Vygotsky proposed that language development produces cognitive development; language is a tool of cognitive development. Bruner focused on how children's language develops from interaction between language and behavior. Bruner also focused on how social reaction allows a child to develop both cognitive concept and language in combination.

The functionalist approach was advocated by Greenfield and Bates. They focused on the function of language and studied that what a child is able to express using language.

Peter Reich studied the strategies for producing words by native English-speaking children. The strategies are syllable deletion, syllable reduplication, deletion of sounds, addition of sounds, substitution of sounds, assimilation of sounds, reversal of sounds, and multiple processes. Syllable deletion is the dropping of unstressed syllables: for example, [æ p] for "apple." Syllable reduplication is not producing a second syllable distinct from the first: for example, "fafa" for "father." Deletion of sounds is the deletion of the final consonant so it is no longer final: for example, "piga" for "pig" and "pulay" for "play." Substitution of sounds is changing sounds: for example, "bak" for "bag," "deebra" for "zebra," "tued" for "shoes," and "doot" for "juice," "pad" for "pan," "wabbit" for "rabbit," and "sue" for "shoe." Assimilation of sounds is "the change of a sound so that it sounds more like another sound in the same word: for example, "fweet" for "sweet." Reversal of sounds is, in producing their first words children get the sounds out of their proper sequence: for example, "aminal" for "animal" and "navilla" for "vanilla." Multiple processes are operated several processes in the same word: for example, $[\mathrm{p} \Lambda \mathrm{s} \Lambda$ ] for "fish" and [bap] for "lamb." (Reich, page 60 62)

\section{[4. Procedure:]}

I visited Yoko's family once a week from October 1994 to February 1996 and taped Yoko's language production. She was between 14 month old (one and a half years old) and 32 months old ( 2 years and 8 months).

[5. Yoko's production of words and sentences:]

At age one year and 4 months

\begin{tabular}{llll} 
apple [æpəlu] & \multicolumn{2}{c}{ bye-bye /bat bai/ } & ball [boul] baby [bebi] \\
horse [hors] & kiddy & [kIdi] & mama [mamə] \\
more [mər] & Micky & [miki] & open [opən] \\
pipi [prpi] stink [t'ipki] & cookie [ki] & banbanman [banbanman]
\end{tabular}


(Analysis of Yoko's production of words.)

1. Deletion of a consonant.

stink [stink] $\rightarrow$ [-t'inki] (Deletion of [s].) cookie [kuki] $\rightarrow[--\mathrm{ki}]$ (Deletion of $[\mathrm{k}]$ and $[\mathrm{U}]$.)

2. Substitution of sounds.

anpanman [anpanman](Japanese word) $\rightarrow$ banbanman [banbanman]

( Substitution of $[b]$ instead of [p].)

stink [stipk] $\rightarrow\left[-t\left[\right.\right.$ Inki] (Substitution of $\left[t^{\circ}\right]$ instead of $[t]$.)

boll [bol] $\rightarrow$ [boul] (Substitution of [ou] instead of [o].)

3. Addition of sounds.

anpanman [anpanman](Japanese word) $\rightarrow$ [banbanman](Addition of [b].)

stink [stıpk] $\rightarrow$ [tipki] (Addition of [i] after the final consonant [k].)

apple [æpəl] $\rightarrow$ [æpəlu] (Addition of [u] after the final consonant [1].)

At age one year and 5 months

eyes [ars] bird [bard] video [bideo]

bloom [blum] more [mor] money [mani]

morning [mornin] monky [m^yki] pencil [pito]

purse [parfi] [porfi] park [parki] coat [korfi] [korfi]

clock [kiton] [kipkon] Daisy [dezi]

keep going /kipgoip/

/wI ji/ and /bIJIJI/ for "Who is this?" and "What is this?"

Japanese words

nani [nani] haidozo/hardozo/ kore [kore] kaki [kaki](write)

(Analysis of Yoko's production of words and sentences.)

1. Substitution of sounds.

eyes $[\mathrm{arz}] \rightarrow$ [ais] (Substitution of $[\mathrm{s}]$ instead of $[z]$ for the plural form.)

video $\left[\mathrm{vId} \varepsilon_{\mathrm{O}}\right] \rightarrow\left[\right.$ bid $\left.\varepsilon_{\mathrm{O}}\right]$ (Substitution of $[\mathrm{b}]$ instead of $[\mathrm{v}]$.)(Japanese sound)

purse [pas] $\rightarrow$ [parfi] (Substitution of [ar] instead of [a] and [ $\left.\int\right]$ instead of [s].)

$\rightarrow$ [porfi] (Substitution of [or] instead of [ $\left[x^{r}\right]$.)

coat $[$ kot $] \rightarrow\left[\right.$ kor $\left.\int i\right]$ and $[$ kor $f i]$ (Substitution of $\left[\int\right]$ or $[t]$ instead of $[t]$.)

2. Addition of sounds.

purse [pars] $\rightarrow$ [par $\left.\int i\right]$ and [por $\left.\int i\right]$ (Addition of [i] after the final consonant [ $]$ ].)

$\operatorname{park}[$ park $] \rightarrow$ [parki] (Addition of [i] after the final consonant $[\mathrm{k}]$.)

coat [kort] $\rightarrow\left[\right.$ kor $\left.\int \mathrm{i}\right]$ and [korfi](Addition of [i] after the final consonant [ $\left.\int\right]$ and [t] $]$.)

3. Yoko's own words.

[wIJi] for "Who is this?" and "What is this?"

[bIJIJI] for "Who is this?" and "What is this?"

[pito] for pencil. 


\section{Kyoko Saito}

[kiton] and [kipkon] for clock.

4. English loan word in Japanese.

video $\left[\right.$ vid $\left.\varepsilon_{0}\right] \rightarrow$ [bid $\left.\varepsilon_{0}\right]$

At age one year 7 months

\begin{tabular}{|c|c|c|}
\hline ear [ir] & fish [fIfi] & horse [hor $\left.\int \mathrm{i}\right]$ \\
\hline finger [pIngar] & juice [dzus] & pig [pIgi] \\
\hline $\begin{array}{l}\left.\text { toes [to } \int\right] \\
\text { anpanman [anpanman] }\end{array}$ & $\begin{array}{l}\text { candy [kændi] } \\
\text { onbu [onbu] }\end{array}$ & $\begin{array}{l}\text { Push it. /puJ It/ } \\
\text { pencil [pInton] }\end{array}$ \\
\hline
\end{tabular}

(Analysis of Yoko's production of 'words and sentences.)

1. Substitution of sounds.

finger [fingar $] \rightarrow[p$ ingar $]$ (Substitution of $[p]$ instead of $[f]$.)

toes $[$ toz $] \rightarrow$ [to $\left.\int\right]$ (Substitution of $\left[\int\right]$ instead of $[z]$ for the plural form.)

horse [hors] $\rightarrow$ [hor $\left.\int i\right]$ (Substitution of [ $\left.\int\right]$ instead of [s].)

2. Addition of sounds.

fish $[\mathrm{fr} J] \rightarrow\left[\mathrm{fr}[\mathrm{i}]\right.$ (Addition of [i] after $\left[\int\right]$.)

pig [pIg] $\rightarrow$ [prgi] (Addition of [i] after [g].)

horse [hors] $\rightarrow$ [hor $\left.\int \mathrm{i}\right]$ (Addition of [i] after [j].)

3. Yoko's own word.

[pinton] for "pencil [pensil]"

At age one year 8 months

\begin{tabular}{|c|c|c|}
\hline beer [bir] & bird [bardi] & boots [buf] \\
\hline coat $[$ kort $]$ & dangerous [d $\varepsilon$ ndzərəs] & fork [fork] \\
\hline Goofy [dufi ] & glove [gləv] & hair $[h \varepsilon r]$ \\
\hline kitty [kIti] & mama's [maməs] & \\
\hline music [mjuzik] & my [maI $]$ & $\operatorname{pin}[p I n]$ \\
\hline please [pliz] & sock [sok] & tree $[\mathrm{ti}]$ \\
\hline ssue [tisu] & finished [frnift] & Kyoko's [kokos] \\
\hline rinkle [sinkəl] & table [jablo] & \\
\hline
\end{tabular}

Sentences

Eat it. /it It/

More soup. /mor sup/

More cheese. /mor tiz/

Daddy's carpet. /dadis kəpet/

I got it. /aI got. It/

All gone bloom. / ol gon blum/

Baby eat lunch. /bebi it lınt/

This's Yokos. /dis s jokos/

I got this. / ar got ð Is/

What's this? /hwat ðIs/ /wI dis/

Who is this? /wI Jis/ 
A Child Language Development

Japanese

maneshite koreshite yoisho otosan okasan Yokochan mouichido

bunbun akachan matemate atatta gojira tepu Atoshi

(Analysis Yoko's production of words and sentences.)

1. Deletion of sounds.

Satoshi [sato $\left.\int \mathrm{i}\right] \rightarrow\left[-\right.$ ato $\left.\int \mathrm{i}\right]$ (Deletion of [s].)

tree $[$ tri $] \rightarrow[t-i]$ (Deletion of $[r]$.)

tissue [tISju] $\rightarrow$ [tIsu] (Deletion of [j].)

Kyoko [kjoko] $\rightarrow$ [koko] (Deletion of [j].)

2. Substitution of sounds.

boots [buts] $\rightarrow$ [but'u] (Substitution of [t'] instead of /ts/.)

Goofy [gufi] $\rightarrow$ [dufi ] (Substitution of [d] instead of [g].)

twinkle [twipkəl] $\rightarrow$ [sipkal] (Substitution of [s] instead of [t].)

daddy's [dædiz ] $\rightarrow$ [dadis] (Substitution of [a]instead of $[æ]$ and [s] instead

of $[z]$ for the possessive case.)

mama's [mamez] $\rightarrow$ [mames] (Substitution of [s] instead of $[z]$ for

the possessive case.)

Kyoko's [kjokoz] $\rightarrow$ [kokos] (Substitution of [s] instead of $[z]$ for

the possessive case.)

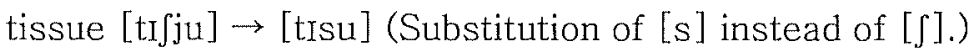

table [tebal] $\rightarrow\left[\int a b a l\right]$ (Substitution of $\left[\int\right]$ instead of [t] and [a] instead of [e].)

What's this? /hwnts ðIs / $\rightarrow$ /hwotf ðIs/ and /wI dis/

(Substitution of $[ə]$ instead of $[\Lambda],[t]$ instead of $[t s]$ and $[d]$ instead of [ð].)

3. Yoko's own words.

/wIJ/for "what's/hwAts/" and "who is/hu Iz/."

At age one year 9 months.

Yoko's [jokos] monkey [monki] tape [tep] apples [æpəls]

socks [soks] boots [buts] coat [kot]

This is Yoko's. /dis s jokos/

Who is this? /hu ðIS/ /WI $\int$ ðIS/ /WI dis/ /WI IS/

Who's this? / wi sIs/

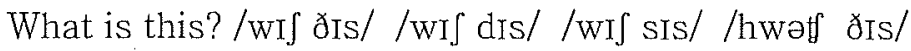

Baby eat it. /bebi it It/

Baby eat lunch. /bebi it lınt']

I got it. /aI gat it/

Daddy's carpet. /dadis parpet/

Japanese 
khoto [kort] bohshi' [borSi] hanashite [hanafite] maneshite/manefite/ waratte/warate/ enpitsu [ $\varepsilon$ npiffu] atoshi [atofi]

(Analysis of Yoko's production of words and sentences.)

1. Deletion of sounds.

This is Yoko's. /ðIs Iz jokoz/ $\rightarrow$ /dis -s jokos/ (Deletion of [I] in "is" .)

What is this? /hwat IZ JIS/ $\rightarrow$ /hwat -s JIS/ (Deletion of [I] in "is".)

Who is this? /hu IZ ðIS/ $\rightarrow$ /WI $\int$ Is/ (Deletion of [ð] in "this" [ðIs].)

2. Substitution of sounds.

This is Yoko's. /JIs Iz jokoz/ $\rightarrow$ /dIs -s jokos/

(Substitution of $[d]$ instead of $[ð]$ in "this" and $[s]$ instead of $[z]$ for the possessive case.)

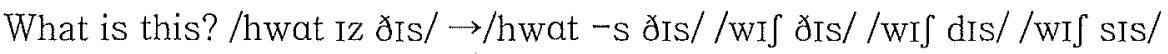

/hwot dis/

(Substitution of $[s]$ instead of $[z]$ in "is", $[d]$ and $[s]$ instead of $[\gamma]$ in "this" .)

Who is this? /hu IZ ðIs/ $\rightarrow$ / wIS ðIs/ /WIS dis/ /wIS ðIs dis/

(Substitution of $[\mathrm{d}]$ instead of [ð] in "this" and / ðIs/ instead of / $\mathrm{r} /$.)

Who's this? /huz ðIs/ $\rightarrow$ /WI $\int$ sIs/

(Substitution of $[\mathrm{s}]$ instead of $[ð]$ in "this" .)

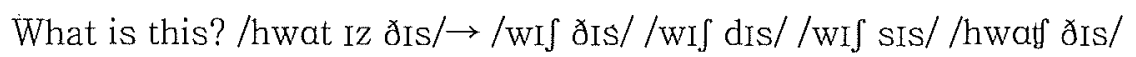

(Substitution of $[d]$ and $[s]$ instead of [ð] in "this" and [f] instead of $[t]$.)

Daddy's carpet. /dædiz karpit/ $\rightarrow$ /dadis parpet/

(Substitution of $[a]$ instead of $[æ],[s]$ instead of $[z]$ for the possessive case,

$[\mathrm{p}]$ instead of $[\mathrm{k}]$ and $[\varepsilon]$ instead of $[\mathrm{I}]$ in "carpet" .)

3. Addition of sound.

enpitsu [Enprt'] $\rightarrow$ [Enprtfu] (Japanese) (Addition of [u] after final consonant.)

4. Yoko's own words.

/wIJ/for "what", "who", "who's", "what is" and "what's".

At age one year 10 months.

(I used only "korenaani" (What is this?) and asked Yoko pointing at pictures.)

boots [buts] pants [pants] pen [pen] Mikey Mouse /miki maus/

doggy [dogi] map [mæp] Goofy [gu $\Phi$ i] fox [foks]

butterfly [bıtərflar] apple [æpəl]

Here, Yoko san. /hrr joko san/

What's this? /hwat $t$ is /

This is mine, red. /ðIs Is main red/ 
Japanese

kore naani bohshi ahiru Satoshi hoshiimo kochimo natto

waratte jaane Kokosan Choko san Yoko san moshigenki

hai douzo daikon

(Analysis of Yoko's production of words and sentences.)

1. Deletion of sound.

Kyoko [kjoko] $\rightarrow$ [koko] (Deletion of [j].)

2. Substitution of sounds.

Goofy [gufi] $\rightarrow$ [gu $\Phi \mathrm{i}]$

(Substitution of $[\Phi]$ instead of $[f]$ but $[\Phi]$ is a Japanese sound.)

What's this? /hwıts ors/ $\rightarrow$ /hwat tis/

(Substitution of [t] instrad of [ts] and [t] instead of [ð].)

This is mine, red. /ðIS IZ maIn $\mathrm{r} \varepsilon \mathrm{d} / \rightarrow$ /ðIS Is maIn red/

(Substitution of $[s]$ instead of $[\dot{z}]$ in "is" .)

Kyoko [kjoko] $\rightarrow[\mathrm{t}$ oko $]$ (Substitution of $[\mathrm{t}]$ instead of $/ / \mathrm{kj} /$.)

\section{At age one year 11 months.}

finger [progar] nose [noz] eyes [ars] Goofy [dufi] pencil [pendel]

Mama here /mame hir/ daddy here /dadi hrr/

You come bed. /ju knm bed/ One to Yoko. /wn to joko/

One to atoshi. /wın tə atofi/ Don't touch it. /dont t $\Delta f$ it/

Were you finish? /wa ju finfl/ Satoshi want. /satofi want/

Pekochan candy. /pekotfan kændi/

Japanese

bukurishita dekita takai takai iyadayo yasashii mama agare

ohanashisuru

(Analysis of Yoko's production of words and sentences.)

1. Deletion of sounds.

Satoshi [sato $\left.\int i\right] \rightarrow\left[-\right.$ ato $\left.\int i\right]$ (Deletion of [s].)

When "Satoshi" [sato $i$ ] is produced as the first word of a sentence, there is no deletion of [s].

2. Substitution of sounds.

finger [frngar $] \rightarrow$ [pingar (Substitution of $[\mathrm{p}]$ instead of $[\mathrm{f}]$.)

eyes [arz] $\rightarrow$ [aIs] (Substitution of $[s]$ instead of $[z]$ for the plural form.)

Goofy [gufi] $\rightarrow$ [dufi] (Substitution of [d] instead of [g].)

pencil [pensəl] $\rightarrow$ [pendəl] (Substitution of [d] instead of [s].)

bikurishita [bikurifita] $\rightarrow$ [bukurifita] (Substition of [u] instead of [i].) 


\section{At age two years.}

fish [fes] many [meni] one [w/n] two [tu] three [Ori] four [for]

five [farv] six [sIks] seven [sevon] eight [et] nine [nain] ten [ten]

\section{Yoko's spontaneous speech}

$\mathrm{K}=$ Kyoko $\mathrm{Y}=$ Yoko

(Y) / al lnv ju koko/ ( I love you Kyoko.)

(K) I love you, too, Yokochan.

(Y) /hwat koko du/ (What Kyoko do?)

(K) Would you like some cookies?

(Y) /no ar dont/ ( No, I don't.)

/ al raid hors/ (I ride horse.)

/ ðe it go tə æ p əl/ (They eat go to apple.)

Japanese

kore naani oshigoto oshiai doubutsu

naniyattano iyadayo yasashii mama

ohanashi suru agare

(Analysis Yoko's production of words and sentences.)

1. Substitution of sounds

fish $\left[\mathrm{fI} \int\right] \rightarrow[\mathrm{f} \varepsilon \mathrm{s}]$ (Substitution of $[\varepsilon]$ instead of [I] and [s] instead of $\left[\int\right]$.)

At age two years 8 months

Yoko's spontaneous speech

$\mathrm{K}=$ Kyoko $\mathrm{Y}=$ Yoko

(Y) Hon yomune. Atode hon yomune. Atode yomu kore. Kore nanda.

(K) Kore wa ghost.

(Y) Nanda kore. /a gost gost gost/ ( A ghost? Ghost. Ghost?)

Obakeyashiki. Obakeyashiki? Obakeyashiki de nai.

Kore wa obakeyashiki.

(K) Yokochan. Where is obakeyashiki?

(Y) Himitsuno $\cdots$.

(K) Door?

(Y) /no nat in ða dorwe nat in ðə dorwe/

(No, not in the doorway. Not in the doorway.)

(K) Have you ever seen a ghost?

(Y) / no aI dont/ (No, I don't.) /hwen In ðə gost/ (When in the ghost.)

(K) Do you want to see ghosts?

(Y) /no aI skerd / (No. I scared.) / aI dont laIk ðعm gost/ ( I don't like them, ghost.) /ju kænt go hom/ (You can't go home?) 
Yoko kaite. Kore Yoko? Kore wa Yoko.

Otosan kaite. /put glæsiz on otosan/ ( Put glasses on otosan.)

Sadosan kaite. /sadosan no nid glæsız/ (Sadosan no need glasses.)

/sadosan don nid glæsiz/ (Sadosan don need glasses.)

(K) Yoko chan kore yonde kudasai. (Please read this, Yoko,)

(Y) Wakannai kore. Kore nanda.

Kore wa tanuki no tame dayo. Kore wa dochi dayo. Kochi.

(K) Jouzu ni yonda, Yoko chan.

(Y) Onaka dashita. Zenbu, zenbu yondanaiyo. Mata onaka dashita.

Konomaewa. Kore nandeshou.

Konohiwa mama deshita. Mama desuka. Yokatta.

Nanika ushiro nite, taihen ni narimashita.

Tanuki no hi wa daijoubu kana. Soudane, soudane.

Ohiru gohan ga dekiagari.

Mama. Mama wa? Okaasan wa? Okaasan obenkyou.

Otosan wa? Otosan oshigoto. Ja, Satoshi wa?

Rusuban to Koko. (留守番と京子) (I stay at home with Kyoko.)

Bye-bye.

(Analysis of Yoko's production of spontaneous speech.)

She used rising intonation for questioning herself such as "a ghost?"

"Kore Yoko?" and "Obakeyashiki?" Then she answered her questions herself as "obakeyashiki de nai" and "kore wa Yoko." She likewise questioned herself, "Mama wa?" "Okaasan wa?" and "Otosanwa?" Again, she answered her questions herself as "Okaasan obenkyou" and "Otosan oshigoto." She also used herself in statements by rephrasing and actually correcting her own English grammar, "/sadosan no nid glæsı// Sadosan no need glasses.)" and "/sadosan don nid glæsiz/(sadosan don need glasses)." Yoko could produce $[z]$ in "glasses" for the plural form.

Yoko could read neither English nor Japanese. As her mother read Japanese children's books in Japanese, Yoko memorized some words and sentences in the story from her mother's production of the story.

\section{[6. Conclusion:]}

There are four language acquisition approaches: the syntactic approach, the behaviorist approach, the cognitive approach, and the functionalist approach.

The syntactic approach focuses on syntactic development, the behaviorist approach focuses on imitation and reinforcement, the cognitive approach shows language development is closely related to cognitive development, and the functionalist 
approach focuses on the function of language.

From my observation of Yoko's production of both English and Japanese, I realized that all four language approaches affected her language development. First, she demonstrated the Language Acquisition Device which represents an innate capacity for learning a natural language. Yoko created her own words and sentences like [pito] and [pinton] for "pencil," [kinton] and [kipkon] for clock, [wTSi]

and /bISISI/ are for "Who is this?" and "What is this?" She also created "Rusuban to Kyoko (留守番と京子)." These words and sentences would not be produced by her mother who is an educated native English speaker and by her father who is an educated native Japanese speaker. To express her thoughts and desires, the functionalist approach was important when Yoko was age two years and eight months. She used rising intonation for questioning like "Kore Yoko?" and "You can't go home?"

Yoko's production of both English and Japanese language had been developed rapidly by the time she was two years and eight months old. Especially, her production of Japanese language was tremendous. It might be because after her brother, Satoshi, entered elementary school, he played with his friends at his home often. Therefore, Yoko could have opportunities to interact with them so she acquired and learned Japanese language.

Listening to her mother's reading Japanese fairy tales in Japanese and the interaction with her brother's friends helped Yoko to acquire and learn Japanese language greatly. When she was two years and eight months old, she could communicate using both English and Japanese. It seems that there was no language barrier between English and Japanese for Yoko.

Bibliography

Reich, Peter. Language Development New Jersey: Prentice-Hall, 1986

Elliot, Alison. Child Language Cambridge: Cambridge University Press, 1981

Loganbill, Bruce. The Bases of Voice, Articulation and Pronunciation Tokyo:

Sanshusha, 1999

Spears, Richard. NTC's American English Learner's Dictionary

NTC Publishing Group,INC. 1998

Saito, Kyoko. "A Native English-Speaking Child's First Language Acquisition"

Language Studies Otaru University of Commerce, 2002 